Check for updates

Cite this: RSC Adv., 2017, 7, 34392

\title{
Fate of nitrogen-15 in the subsequent growing season of greenhouse tomato plants (Lycopersicon esculentum Mill) as influenced by alternate partial root-zone irrigation
}

\author{
Maomao Hou, (D) *a Fenglin Zhong, ${ }^{\text {a }}$ Qiu Jin, ${ }^{\mathrm{b}}$ Enjiang Liu, ${ }^{\mathrm{c}}$ Jie Feng, ${ }^{\mathrm{a}}$ Tengyun Wang ${ }^{\mathrm{a}}$ \\ and Yue $\mathrm{GaO}^{\mathrm{c}}$
}

\begin{abstract}
Alternate partial root-zone irrigation (APRI) has profound impacts on the distribution of nitrogen fertilizer applied in-season. However, the fate of previous residual nitrogen in the subsequent crop growing season under APRI has seldom been studied. Our objective in this study was to investigate the effects of APRI on the reutilization, redistribution and loss of residual nitrogen in the subsequent season. To achieve this objective, in the previous season, greenhouse tomatoes (Lycopersicon esculentum Mill) were chosen as a plant material, and were treated with two irrigation patterns (APRI and conventional irrigation (CI)), two ${ }^{15} \mathrm{~N}$ labeling depths $\left(\mathrm{K}^{15} \mathrm{NO}_{3}\right.$ with a ${ }^{15} \mathrm{~N}$ abundance of $10.57 \%$, labeled in the $0-20 \mathrm{~cm}$ and $40-60 \mathrm{~cm}$ soil layers, respectively) and two transplant times (early and late summer). In the subsequent season, we adopted the same irrigation patterns, but with no ${ }^{15} \mathrm{~N}$ labeled in the soil. Our results showed that $81.3-90.7 \%$ of the residual ${ }^{15} \mathrm{~N}$ from the previous season still remained in the $0-$ $100 \mathrm{~cm}$ soil layer, $4.1-7.3 \%$ was absorbed by the subsequent-season tomatoes, and $2.9-14.6 \%$ was lost. The ${ }^{15} \mathrm{~N}$ reutilization rates (defined as the ratio of ${ }^{15} \mathrm{~N}$ uptake by the subsequent tomatoes to the total applied ${ }^{15} \mathrm{~N}$ ) were $2.20-4.73 \%$ under the different treatments (the ${ }^{15} \mathrm{~N}$ utilization rates of the in-season tomatoes were $18.8-27.9 \%)$. Compared to $\mathrm{Cl}$, APRI significantly $(p<0.05)$ increased the plant ${ }^{15} \mathrm{~N}$ uptake and ${ }^{15} \mathrm{~N}$ reutilization rate, and APRI also contributed to a greater mineral and organic ${ }^{15} \mathrm{~N}$ amount in shallower soil layers. Overall, the tomato ${ }^{15} \mathrm{~N}$ reutilization rate was found to be significantly $(p<0.05)$ higher when ${ }^{15} \mathrm{~N}$ labeling was performed in the $0-20 \mathrm{~cm}$ soil layer compared to that in the $40-60 \mathrm{~cm}$ layer. Moreover, the ${ }^{15} \mathrm{~N}$ reutilization rate had a significant positive relationship with the root dry weight $\left(R=0.74 *\right.$, root length density $(R=0.72 *)$, soil mineral ${ }^{15} \mathrm{~N}(R=0.91 * *)$ and total residual ${ }^{15} \mathrm{~N}$ amount $(R$ $=0.88 * *$.
\end{abstract}

Received 10th May 2017

Accepted 22nd June 2017

DOI: $10.1039 / \mathrm{c} 7 \mathrm{ra05271e}$

rsc.li/rsc-advances not only in China, but also in many other countries. ${ }^{7-9}$ For greenhouse-covered arable fields, the situation of nitrogen residues is worsening. China can apply 569-2000 $\mathrm{kg} \mathrm{ha}^{-1}$ of pure nitrogen during one season of production of greenhouse crops, which is several times or even dozens of times over that applied to ordinary field crops, leading to a large quantity of nitrogen residues ${ }^{\mathbf{1 0}}$ and losses. ${ }^{\mathbf{1 1}}$ Among different forms of residual nitrogen, nitrate-nitrogen $\left(\mathrm{NO}_{3}{ }^{-}-\mathrm{N}\right)$ is characterized as easily leached; ${ }^{12} \mathrm{NO}_{3}{ }^{-}-\mathrm{N}$ is hard to convert to other forms in deeper soil layers, and therefore it not only pollutes surface water through runoffs, but also poses a serious threat to underground water environments. ${ }^{13}$

Greenhouse agriculture in northern China suffers from high $\mathrm{NO}_{3}{ }^{-}-\mathrm{N}$ residues, as well as severe water shortages. The distribution of water resources in China is geographically uneven, with $81 \%$ of the total water resources being intensively distributed in the Yangtze River basin and southern regions. Specifically, there is ten times more fresh water per capita in the
China.E-mail: njhoumaomao@126.com

${ }^{b}$ Institute of Water Conservancy Science of Jiangsu Province, Nanjing 210000, Jiangsu, China

${ }^{c}$ Development and Reform Commission of Suihua, Suihua, Heilongjiang, China 
south than the north. ${ }^{\mathbf{1 4}}$ Thus, for agricultural production in northern China, it is of great importance to utilize water resources efficiently and control the outputs of agricultural contaminants.

Efforts have been made to employ innovative irrigation methods to promote the growth of crop roots, and to recover the residual nitrogen fertilizer in the soil. ${ }^{15,16}$ A study using ${ }^{15} \mathrm{~N}$ labeling has revealed that water-saving irrigation is conducive to winter wheat recovering nitrogen fertilizer in the deeper soil layer at $100-150 \mathrm{~cm}^{17}$ Alternate partial root-zone irrigation (APRI) is one component of partial root-zone irrigation (PRI). As a relatively new water-saving irrigation technique, APRI has now been applied in the production of soybean, peppers, apples, potatoes, tomatoes, cotton, grapes, etc. ${ }^{18}$ In APRI, half of the root-zone is irrigated while the other half is allowed to dry, and then the previously well-watered side of the root system is allowed to dry while the previously dried side is irrigated when the next irrigation occurs. ${ }^{15}$ Earlier results have demonstrated that APRI can significantly save irrigation water without significantly decreasing the yield. ${ }^{19,20}$ APRI has also been proved to promote dry matter accumulation in the roots and increase the root length density. ${ }^{21}$ Although many studies have investigated the impact of APRI on crop yield and water use, few studies have focused on how APRI influences the crop $\mathrm{NO}_{3}{ }^{-}-\mathrm{N}$ uptake, and no research has studied the fate and balance of applied nitrogen fertilizers in the subsequent growing season of the crop under the influence of APRI.

In our previous study in 2014, we labeled $\mathrm{K}^{15} \mathrm{NO}_{3}$ (abundance of $10.57 \%$ ) in different soil layers at $0-20$ and $40-60 \mathrm{~cm}$, and studied the impact of alternate partial root-zone irrigation on the ${ }^{15} \mathrm{~N}$ uptake of greenhouse tomatoes. We found that APRI had a profound impact on the distribution of in-season applied fertilizer nitrogen. ${ }^{22}$ The objective of this study (conducted in 2015) was to investigate the fate and balance of previous residual ${ }^{15} \mathrm{~N}$ in the subsequent growing season of greenhouse tomatoes, as influenced by APRI. Details included: (1) the reutilization of ${ }^{15} \mathrm{~N}$ by the subsequent tomatoes; (2) the distribution of ${ }^{15} \mathrm{~N}$ in different soil layers; (3) the balance of ${ }^{15} \mathrm{~N}$ in the subsequent growing season. The study conclusions are expected to provide useful information for those in areas suffering from an agricultural water shortage and excessive nitrogen residues.

\section{Materials and methods}

\section{Experimental site description and the previous experiment}

The experiments were conducted in 2015 at the Production Base of Greenhouse Vegetables (longitude $126^{\circ} 22^{\prime} \mathrm{E}$, latitude $46^{\circ} 12^{\prime} \mathrm{N}$ ) of Lanxi county, Suihua city, Heilongjiang province. Suihua belongs to the northern hemisphere temperate zone; it has four clear seasons, with snow cover in winter, while being warm and humid in summer. The annual average temperature from 2000 to 2013 in Suihua ranged from $1.3{ }^{\circ} \mathrm{C}$ to $4.0^{\circ} \mathrm{C}$. There is an annual duration of 120-140 days in the frost-free season, and a sunshine duration of 2600-2900 h. The annual average precipitation in Suihua is $483 \mathrm{~mm}$. Precipitation occurs intensively in July and August. The experiment was carried out in a solar greenhouse. The span of the greenhouse is $10 \mathrm{~m}$, the length is $8 \mathrm{~m}$ and the height of the back wall is $3 \mathrm{~m}$. For ventilation and cooling in summer, several vents were installed in the back wall with $1 \mathrm{~m}$ height above the ground; for details, see Fig. 1. Crop seedlings were transplanted separately in early and late summer. The day/night average temperature was 24.7/ $20.2{ }^{\circ} \mathrm{C}$ in early summer, and $21.3 / 18.5{ }^{\circ} \mathrm{C}$ in late summer, during the whole growth stage of the crop.

Since this experiment constitutes a second part of our previous work, here we briefly introduce the previous experiment: ${ }^{22}$

The previous experiment was carried out in 2014 in the abovementioned greenhouse. The physical and chemical attributes of the original soil were determined as shown in Table 1. The tomato (Lycopersicon esculentum Mill) cultivar "Red Ruby" was used as the plant material. The experiment included two irrigation patterns (APRI and conventional irrigation (CI)), two ${ }^{15} \mathrm{~N}$ labeling locations in the soil layers (0-20 and 20-40 cm), and two transplant times (early and late summer). The transplant dates in 2014 for early and late summer were June 18 and August 22, respectively. For details of the experimental design, see Table 2 . As was recorded, the total irrigation amount of CI and APRI was 498 and $324 \mathrm{~mm}$, respectively, at the transplant time of early summer, and 476 and $310 \mathrm{~mm}$ at that of late summer.

Several soil columns that were pre-buried in the soil were used for the experiment. The soil columns were prepared using a PVC cylindrical mold. The height of the PVC mold was $1 \mathrm{~m}$ and the diameter was $40 \mathrm{~cm}$, with the bottom unsealed. Plastic film was employed and kept close to the inner side of the mold. The soils were dug out by $20 \mathrm{~cm}$ in each layer and then filled back into the mold as the field's original soil layers. The backfilled soils inside and outside of the mold were kept at the same height during the filling process in order to avoid the deflection of the mold. To provide the nutrients that are needed by the tomato plants, the $0-20 \mathrm{~cm}$ layer of the soil was mixed with $100 \mathrm{mg} \mathrm{kg}^{-1} \mathrm{~N}, 150 \mathrm{mg} \mathrm{kg}^{-1} \mathrm{P}_{2} \mathrm{O}_{5}$ and $150 \mathrm{mg} \mathrm{kg}^{-1} \mathrm{~K}_{2} \mathrm{O}$. These pure nutrients came from $\mathrm{NH}_{4} \mathrm{NO}_{3}, \mathrm{Ca}\left(\mathrm{H}_{2} \mathrm{PO}_{4}\right)_{2}$ and $\mathrm{K}_{2} \mathrm{SO}_{4}$, respectively. The ${ }^{15} \mathrm{~N}$ used for labeling was $\mathrm{K}^{15} \mathrm{NO}_{3}$ (abundance of $10.57 \%$ ), and the ${ }^{15} \mathrm{~N}$ was labeled to a thickness of $10 \mathrm{~cm}$, as is displayed in Fig. 2. The dosage of ${ }^{15} \mathrm{~N}$ was $466 \mathrm{mg}$ for each soil column. After finishing the soil backfilling and ${ }^{15} \mathrm{~N}$ labeling, the molds were taken out from the field, only leaving the plastic film to separate the soils inside and outside the columns. At 55 and 76 DAT, dissolved urea was applied two times as additional fertilizer, and each time the application amount was $60 \mathrm{mg} \mathrm{kg}^{-1}$ N. For each APRI treatment, a film separator $(20 \mathrm{~cm}$ height) was

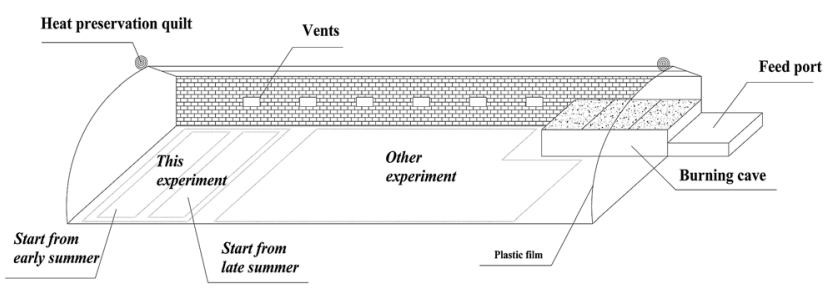

Fig. 1 The solar greenhouse used in this experiment (the day/night average temperature was $24.7 / 20.2{ }^{\circ} \mathrm{C}$ in early summer, and $21.3 /$ $18.5^{\circ} \mathrm{C}$ in late summer, during the whole growth stage of the crop). ${ }^{22}$ 
Table 1 The physical and chemical attributes of the soil in the greenhouse

\begin{tabular}{|c|c|c|c|c|c|c|c|}
\hline $\begin{array}{l}\text { Soil depth } \\
(\mathrm{cm})\end{array}$ & $\mathrm{pH}$ & $\begin{array}{l}\text { Bulk density } \\
\left(\mathrm{g} \mathrm{cm}^{-3}\right)\end{array}$ & $\begin{array}{l}\text { Organic matter } \\
\left(\mathrm{g} \mathrm{kg}^{-1}\right)\end{array}$ & $\begin{array}{l}\text { Available N } \\
\left(\mathrm{mg} \mathrm{kg}^{-1}\right)\end{array}$ & $\begin{array}{l}\text { Available P } \\
\left(\mathrm{mg} \mathrm{kg}^{-1}\right)\end{array}$ & $\begin{array}{l}\text { Available K } \\
\left(\mathrm{mg} \mathrm{kg}^{-1}\right)\end{array}$ & $\begin{array}{l}\text { Total N } \\
\left(\mathrm{g} \mathrm{kg}^{-1}\right)\end{array}$ \\
\hline $0-10$ & 7.37 & 1.39 & 14.71 & 122.4 & 18.81 & 121.3 & 1.40 \\
\hline $10-20$ & 7.44 & 1.42 & 10.93 & 105.7 & 14.92 & 106.2 & 1.25 \\
\hline $20-60$ & 7.65 & 1.55 & 8.62 & 91.6 & 5.33 & 63.4 & 0.78 \\
\hline $60-100$ & 7.91 & 1.51 & 5.36 & 61.3 & 3.21 & 35.5 & 0.39 \\
\hline
\end{tabular}

Table 2 Experimental design of ${ }^{15} \mathrm{~N}$ labeling, irrigation method and transplanting time in the 2014 season $^{a}$

\begin{tabular}{lllll}
\hline $\begin{array}{l}\text { Transplant } \\
\text { time }\end{array}$ & Treatment & $\begin{array}{l}\text { Transplant } \\
\text { date }\end{array}$ & $\begin{array}{l}\text { Irrigation } \\
\text { pattern }\end{array}$ & $\begin{array}{l}\text { Depth of }{ }^{15} \mathrm{~N} \\
\text { labeling }(\mathrm{cm})\end{array}$ \\
\hline Early summer & APRI10 & June 18 & APRI & $0-20$ \\
& CI10 & June 18 & CI & $0-20$ \\
& APRI50 & June 18 & APRI & $40-60$ \\
& CI50 & June 18 & CI & $40-60$ \\
Late summer & APRI10 & August 22 & APRI & $0-20$ \\
& CI10 & August 22 & CI & $0-20$ \\
& APRI50 & August 22 & APRI & $40-60$ \\
& CI50 & August 22 & CI & $40-60$
\end{tabular}

${ }^{a}$ Note: APRI represents alternate partial root-zone irrigation, and CI represents conventional irrigation.

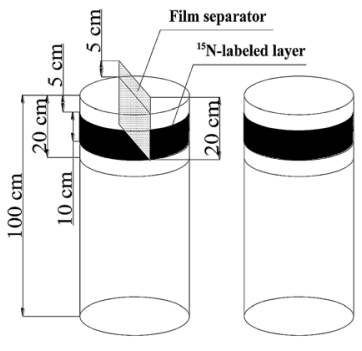

(1)

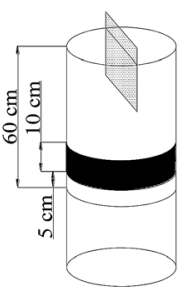

(3)

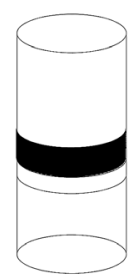

(4)
Fig. 2 Diagrammatic sketch of ${ }^{15} \mathrm{~N}$ labeling in the soil columns in 2014 (soil columns (1) and (3) are for the plants with alternate partial rootzone irrigation, and columns (2) and (4) are for the plants with conventional irrigation). ${ }^{22}$

buried in the middle of each soil column, leaving $5 \mathrm{~cm}$ height out of the soil surface (Fig. 2). The film separator had a gap in its center for transplanting the tomato seedlings. Fig. 3 displays the arrangement of the soil columns. The distance between two adjacent columns was $20 \mathrm{~cm}$, and the distance between two plots for different transplant times was $40 \mathrm{~cm}$. Fig. 1-3 can also be seen in our previous study. ${ }^{22}$

After the experiment, the total amount of ${ }^{15} \mathrm{~N}$ remaining in the soil at 0-100 cm was $251.4-309.6 \mathrm{mg}$ per column; for details, see ref. 22.

\section{Experimental design}

This study (2015) was conducted to investigate the fate of residual ${ }^{15} \mathrm{~N}$ from the previous experiment (2014), therefore this

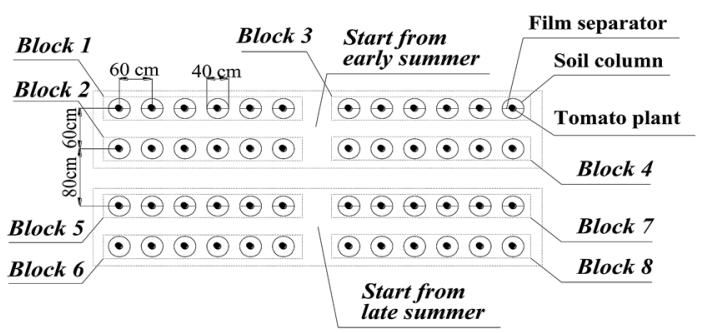

Fig. 3 The arrangement of soil columns (in blocks 1 and 5, the plants are treated with alternate partial root-zone irrigation, and ${ }^{15} \mathrm{~N}$ is labeled at $10 \mathrm{~cm}$ depth in the soil; in blocks 3 and 7 , the plants are treated with alternate partial root-zone irrigation, and ${ }^{15} \mathrm{~N}$ is labeled at $50 \mathrm{~cm}$ depth in the soil; in blocks 2 and 6 , the plants are treated with conventional irrigation, and ${ }^{15} \mathrm{~N}$ is labeled at $10 \mathrm{~cm}$ depth in the soil; in blocks 4 and 8 , the plants are treated with conventional irrigation, and ${ }^{15} \mathrm{~N}$ is labeled at $50 \mathrm{~cm}$ depth in the soil). ${ }^{22}$

experiment was carried out in situ. After the experiment in 2014, no crops were planted in the soil columns until starting this experiment. The soils in the $0-20 \mathrm{~cm}$ layer for each soil column were ploughed before the tomato planting of this season.

This experiment adopted the same irrigation patterns as our previous study in 2014, namely APRI and CI. An earlier study conducted in a solar greenhouse in northern China proved that the tomato water use efficiency, yield and quality could reach an optimal compromise when controlling the lower limit of soil moisture at $70 \% \theta_{\mathrm{f}}$ (field capacity) and the upper limit at $90 \%$ $\theta_{\mathrm{f}}{ }^{23}$ Thus, during the whole growth stage of the tomato plants, the soil moisture of $\mathrm{CI}$ in this study was controlled at a lower limit of $70 \% \theta_{\mathrm{f}}$, and an upper limit of $90 \% \theta_{\mathrm{f}}$. Moreover, earlier results demonstrated that APRI saved $40 \%$ irrigation water, while not significantly reducing the crop yield. ${ }^{21,24}$ According to this information, the total irrigation amount of APRI in our study was designed as $60 \%$ of the amount of CI. An irrigation amount of $62 \mathrm{~mm}$ was applied for the survival of the seedlings during 0-28 DAT (days after transplant), for the transplant times of both early and late summer. After that, the tomatoes were irrigated with different patterns of APRI and CI.

Moreover, the fertilization and transplant times in this experiment were also the same as those in 2014, while in this study no ${ }^{15} \mathrm{~N}$ was labeled in the soil. The transplant date was June 15 for the transplant time of early summer, and August 17 for that of late summer. The total irrigation amount of CI and APRI was recorded as 501 and $325 \mathrm{~mm}$ for the tomatoes transplanted in early summer, and 486 and $316 \mathrm{~mm}$ for those transplanted in late summer. 


\section{Sampling and measurement}

For both transplant times in 2015, plant samples were collected separately as root, stem, fruit and leaf (including ordinary leaves and fallen leaves) samples after the last harvest; meanwhile, soil samples were collected using a diminutive soil auger at $10 \mathrm{~cm}$ per layer. Ten samples were collected in the $0-100 \mathrm{~cm}$ soil layer for each soil column.

(1) ${ }^{15} \mathrm{~N}$ atom percentage excess: air-dried soil samples were ground and passed through a $0.15 \mathrm{~mm}$ sieve for measuring the ${ }^{15} \mathrm{~N}$ atom percentage excess. Mineral nitrogen in fresh soil samples was extracted using $2 \mathrm{M} \mathrm{KCl}$ and distilled using micro Kjeldahl apparatus, in the presence of $\mathrm{MgO}$ and Devarda alloy. ${ }^{25}$ The ${ }^{15} \mathrm{~N}$ atom percentage excess in the sample was determined using a mass spectrometer (Finniga-Mat-251, Mass-Spectrometers, Finnigan, Germany) at Nanjing Institute of Soil Science, CAS.

(2) Root length density: root samples from the tomato plants were cleaned and scanned using an EPSON EXPRESSION 1680 scanner, and then analyzed using WinRHIZO software to obtain the data on root length density.

(3) Root dry matter: fresh root samples from tomato plants were placed in an oven, and dried firstly at $105{ }^{\circ} \mathrm{C}$ for $30 \mathrm{~min}$, and then at $70{ }^{\circ} \mathrm{C}$ until a constant weight was achieved.

\section{Calculations and statistical analysis}

(1) Reutilization rate of ${ }^{15} \mathrm{~N}\left({ }^{15} \mathrm{NUE}, \%\right) .{ }^{15} \mathrm{NUE}$ was calculated as: ${ }^{1}$

$$
\begin{gathered}
N_{\text {dff }}=C_{\mathrm{s}} \times \frac{E_{\mathrm{s}}}{E_{\mathrm{f}}} \\
{ }^{15} \mathrm{NUE}=\left(\frac{N_{\mathrm{dff}}}{M_{\mathrm{f}}}\right) \times 100 \%
\end{gathered}
$$

where $N_{\mathrm{dff}}$ is the ${ }^{15} \mathrm{~N}$ amount in the tomato plants $(\mathrm{mg}), C_{\mathrm{s}}$ is the total $\mathrm{N}$ amount in the tomato plants $(\mathrm{mg}), E_{\mathrm{s}}$ is the ${ }^{15} \mathrm{~N}$ atom percentage excess in the tomato plants, $E_{\mathrm{f}}$ is the ${ }^{15} \mathrm{~N}$ atom percentage excess in the ${ }^{15} \mathrm{~N}$ labeled fertilizer, and $M_{\mathrm{f}}$ is the amount of ${ }^{15} \mathrm{~N}$ fertilizer applied in $2014(\mathrm{mg})$.

(2) Organic ${ }^{15} \mathrm{~N}$. The organic ${ }^{15} \mathrm{~N}$ content in each soil layer was calculated as the difference between the total ${ }^{15} \mathrm{~N}$ minus the mineral ${ }^{15} \mathrm{~N}$ in the respective soil layer. ${ }^{25}$
(3) ${ }^{15} \mathrm{~N}$ recovery amount (mg per soil column). The amount of ${ }^{15} \mathrm{~N}$ recovery was the sum of the residual ${ }^{15} \mathrm{~N}$ in the $0-100 \mathrm{~cm}$ soil layer and the ${ }^{15} \mathrm{~N}$ uptake by the tomato plants. ${ }^{26}$

(4) ${ }^{15} \mathrm{~N}$ loss (mg per soil column). The amount of ${ }^{15} \mathrm{~N}$ loss is calculated using the applied ${ }^{15} \mathrm{~N}$ amount minus the ${ }^{15} \mathrm{~N}$ recovery amount. ${ }^{11}$

The data were compared statistically using SPSS software Version 17.0..$^{27}$

\section{Results}

\section{${ }^{15} \mathrm{~N}$ uptakes in different plant parts}

APRI significantly $(p<0.05)$ increased the ${ }^{15} \mathrm{~N}$ accumulation in all plant parts except for the stem in the plants transplanted in early summer (Table 3). The ${ }^{15} \mathrm{~N}$ amount under APRI was increased by $37.9-53.4 \%, 10.1-38.3 \%, 36.6-73.1 \%$ and $47.1-$ $61.9 \%$, respectively in the leaves, stems, roots and fruits of the tomato plants, when compared to those under CI.

For each plant part, the difference in ${ }^{15} \mathrm{~N}$ amount at the different labeling depths but under the same irrigation pattern was significant $(p<0.05)$, except for some unrepresentative cases. In treatments with ${ }^{15} \mathrm{~N}$ labeled at the soil depth of $10 \mathrm{~cm}$, the ${ }^{15} \mathrm{~N}$ amount in the leaves, stems, roots and fruits of the tomato plants was $15.0-42.3 \%, 7.7-56.2 \%, 20.5-59.2 \%$ and $13.2-44.8 \%$ higher than that labeled at a depth of $50 \mathrm{~cm}$.

Although a delay in the transplant time slightly decreased the ${ }^{15} \mathrm{~N}$ accumulative amount in the respective plant parts, the decrease was not significant $(p>0.05)$ overall. A noticeable decrease in ${ }^{15} \mathrm{~N}$ caused by transplant time was found in the stem under APRI50 and CI50, and in the roots under APRI50.

\section{Total ${ }^{15} \mathrm{~N}$, mineral ${ }^{15} \mathrm{~N}$ and organic ${ }^{15} \mathrm{~N}$ in the soil layers}

Fig. 4 displays the profiles of total ${ }^{15} \mathrm{~N}$, mineral ${ }^{15} \mathrm{~N}$ and organic ${ }^{15} \mathrm{~N}$ in the $0-100 \mathrm{~cm}$ soil layer under different treatments. From the distribution of total ${ }^{15} \mathrm{~N}$, it was found that the peak value under APRI10, CI10, APRI50 and CI50 appeared at a soil depth of 30, 40, 50 and $60 \mathrm{~cm}$, respectively. Similar trends were obtained with the transplant time of both early and late summer. Compared to CI, APRI reserved $48.6-176.3 \%$ more ${ }^{15} \mathrm{~N}$ in the respective labeled layer. Under the same treatment (irrigation and labeling), the distribution of total ${ }^{15} \mathrm{~N}$ was similar between

Table 3 The amount of ${ }^{15} \mathrm{~N}$ absorbed by different plant parts in the 2015 season $^{a}$

\begin{tabular}{llllll}
\hline Transplant time & Treatment & Leaf $(\mathrm{mg}$ per plant) & Stem (mg per plant) & Root (mg per plant) & Fruit (mg per plant) \\
\hline Early summer & APRI10 & $7.68 \pm 0.34 \mathrm{a}$ & $2.14 \pm 0.10 \mathrm{a}$ & $1.23 \pm 0.09 \mathrm{a}$ & $10.99 \pm 1.40 \mathrm{a}$ \\
& CI10 & $5.00 \pm 0.45 \mathrm{~b}$ & $1.94 \pm 0.07 \mathrm{ab}$ & $0.82 \pm 0.07 \mathrm{bc}$ & $6.89 \pm 1.28 \mathrm{c}$ \\
& APRI50 & $5.40 \pm 0.35 \mathrm{~b}$ & $1.99 \pm 0.11 \mathrm{ab}$ & $0.93 \pm 0.03 \mathrm{~b}$ & $8.95 \pm 0.36 \mathrm{~b}$ \\
Late summer & CI50 & $3.75 \pm 0.28 \mathrm{c}$ & $1.54 \pm 0.20 \mathrm{~d}$ & $0.68 \pm 0.03 \mathrm{~cd}$ & $6.08 \pm 0.74 \mathrm{~cd}$ \\
& APRI10 & $6.99 \pm 0.41 \mathrm{a}$ & $2.05 \pm 0.13 \mathrm{a}$ & $1.26 \pm 0.04 \mathrm{a}$ & $10.78 \pm 0.73 \mathrm{a}$ \\
& CI10 & $4.59 \pm 0.26 \mathrm{bc}$ & $1.80 \pm 0.04 \mathrm{bc}$ & $0.73 \pm 0.06 \mathrm{c}$ & $6.78 \pm 0.70 \mathrm{c}$ \\
& APRI50 & $5.51 \pm 0.90 \mathrm{~b}$ & $1.59 \pm 0.04 \mathrm{~cd}$ & $0.79 \pm 0.04 \mathrm{c}$ & $7.37 \pm 0.37 \mathrm{bc}$ \\
& CI50 & $3.99 \pm 0.15 \mathrm{c}$ & $1.15 \pm 0.06 \mathrm{e}$ & $0.58 \pm 0.09 \mathrm{~d}$ & $0.59 \mathrm{~d}$
\end{tabular}

${ }^{a}$ Note: APRI10 and APRI50 represent that ${ }^{15} \mathrm{~N}$ was labeled at 10 and $50 \mathrm{~cm}$ soil depths, respectively, under alternate partial root-zone irrigation, and CI10 and CI50 represent that ${ }^{15} \mathrm{~N}$ was labeled at 10 and $50 \mathrm{~cm}$ soil depths, respectively, under conventional irrigation in the 2014 season. In the same column, means followed by the same letter (a, b, c, d, or e) do not differ significantly at the $5 \%$ level, according to Duncan's multiple range test. Each value is the mean $\pm \mathrm{SD}$. 

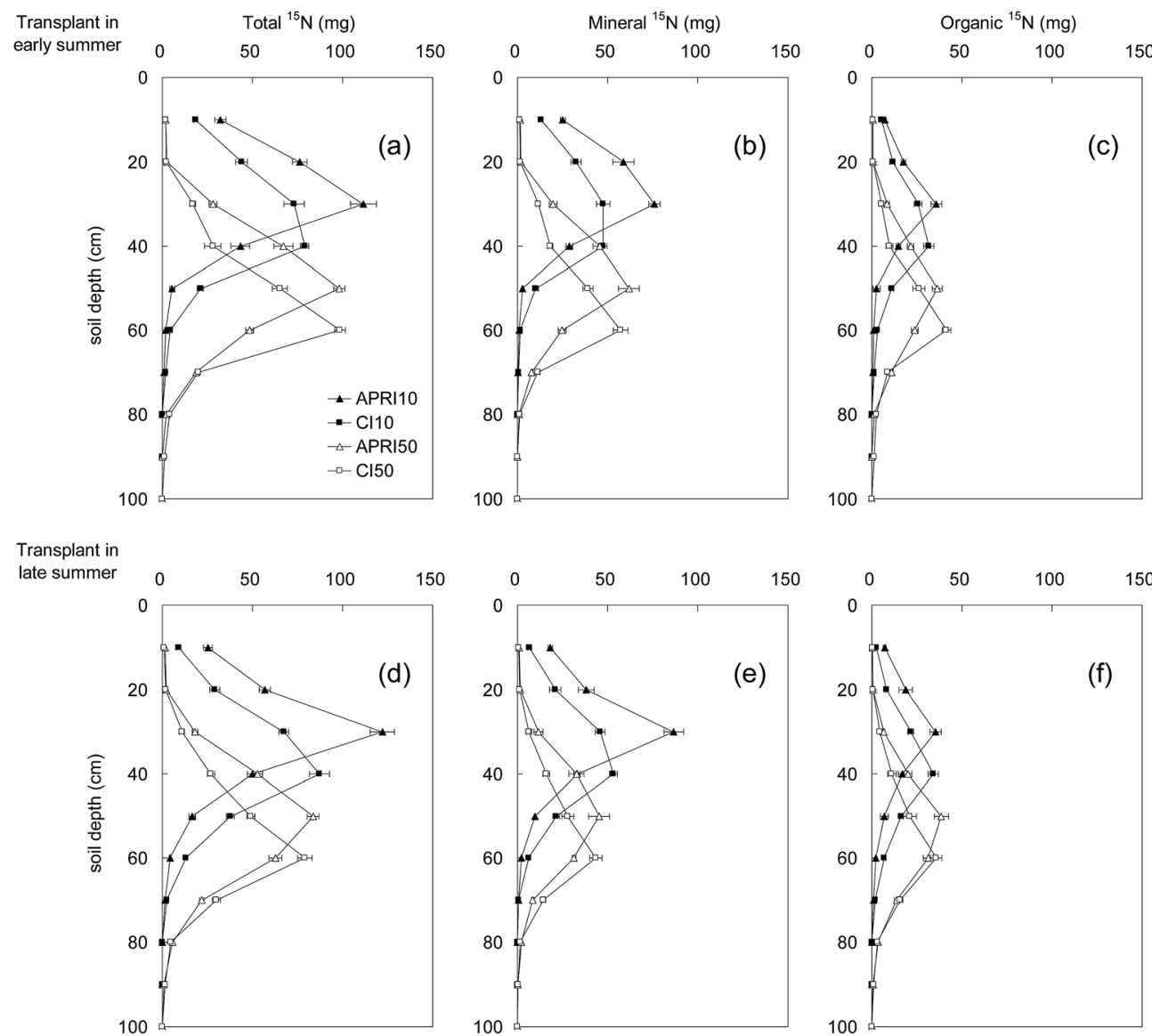

Fig. 4 Profiles of total ${ }^{15} \mathrm{~N}$, mineral ${ }^{15} \mathrm{~N}$ and organic ${ }^{15} \mathrm{~N}$ in the $0-100 \mathrm{~cm}$ soil layer at the transplant time of early summer (a-c) and late summer (d-f) (APRI10 and APRI50 represent that ${ }^{15} \mathrm{~N}$ was labeled at 10 and $50 \mathrm{~cm}$ soil depths, respectively, under alternate partial root-zone irrigation, and $\mathrm{Cl} 10$ and $\mathrm{Cl} 50$ represent that ${ }^{15} \mathrm{~N}$ was labeled at 10 and $50 \mathrm{~cm}$ soil depths, respectively, under conventional irrigation in the 2014 season; error bars are standard errors of the mean).

the different transplant times, while the amount of total ${ }^{15} \mathrm{~N}$ was found to be lower with the transplant time of late summer.

Mineral ${ }^{15} \mathrm{~N}$ and organic ${ }^{15} \mathrm{~N}$ were distributed analogously in the soil layers to the total ${ }^{15} \mathrm{~N}$. As is shown in Fig. $4(\mathrm{~b}-\mathrm{e})$, the ${ }^{15} \mathrm{~N}$ in the soil was mainly present in the mineral form. When the ${ }^{15} \mathrm{~N}$ was labeled at $10 \mathrm{~cm}$ depth, the mineral ${ }^{15} \mathrm{~N}$ in the $0-30 \mathrm{~cm}$ layer under APRI was significantly $(p<0.05)$ higher than that under CI. And when the ${ }^{15} \mathrm{~N}$ was labeled at $50 \mathrm{~cm}$ depth, the mineral ${ }^{15} \mathrm{~N}$ in the $0-50 \mathrm{~cm}$ layer under APRI was significantly ( $p$ $<0.05$ ) higher than that under CI.

Overall, the transplant time in our study did not significantly change the distribution of total ${ }^{15} \mathrm{~N}$, mineral ${ }^{15} \mathrm{~N}$ or organic ${ }^{15} \mathrm{~N}$ in the $0-100 \mathrm{~cm}$ soil layer. However, the irrigation pattern had clear effects on the ${ }^{15} \mathrm{~N}$ accumulation and distribution in the soil layers. APRI contributed greatly to the preservation of ${ }^{15} \mathrm{~N}$ in a shallower soil layer relative to $\mathrm{CI}$, for the ${ }^{15} \mathrm{~N}$ labeling depths of both 10 and $50 \mathrm{~cm}$.

\section{Distribution and balance of ${ }^{15} \mathrm{~N}$}

The distribution and balance of ${ }^{15} \mathrm{~N}$ is shown in Table 4 . After the experiment in 2015, the accumulation amount of ${ }^{15} \mathrm{~N}$ in the 0-100 cm soil layer was in the range of $204.5-276.4 \mathrm{mg}$ per soil column, accounting for $81.3-90.7 \%$ of the original ${ }^{15} \mathrm{~N}$ amount. The greatest ${ }^{15} \mathrm{~N}$ accumulation amount in the soil was achieved by APRI10, and the difference between the two transplant times was not significant $(p>0.05)$. The irrigation pattern had an obvious influence on the accumulation amount of ${ }^{15} \mathrm{~N}$ in the soil, as APRI increased it significantly $(p<0.05)$ by $10.8-18.0 \%$; the greatest increment was found between APRI50 and CI50 when the tomato plants were transplanted in late summer. Otherwise, a deeper ${ }^{15} \mathrm{~N}$ labeling depth resulted in a lower accumulation amount of ${ }^{15} \mathrm{~N}$ in the soil; this was particularly obvious for the transplant time of late summer. Overall, the plant ${ }^{15} \mathrm{~N}$ uptake was significantly $(p<0.05)$ increased by APRI in comparison to $\mathrm{CI}$, and was also significantly $(p<0.05)$ increased by a $10 \mathrm{~cm}$ labeling depth in comparison to $50 \mathrm{~cm}$. Although a slight increase in ${ }^{15} \mathrm{~N}$ uptake was also detected in the tomatoes transplanted in early summer compared to those transplanted in late summer, the increase was not significant ( $p$ $>0.05$ ).

After the experiment in the 2015 season, the amount of ${ }^{15} \mathrm{~N}$ recovery under the different treatments was found to range from 214.7 to $297.5 \mathrm{mg}$, and the amount of ${ }^{15} \mathrm{~N}$ loss ranged from 8.7 to $36.7 \mathrm{mg}$. The recovery and loss amount of ${ }^{15} \mathrm{~N}$ in the 2015 
Table 4 The balance of ${ }^{15} \mathrm{~N}$ under different treatments in the 2015 season ${ }^{a}$

\begin{tabular}{|c|c|c|c|c|c|}
\hline Transplant time & Treatment & $\begin{array}{l}\text { Residual }{ }^{15} \mathrm{~N} \text { from the } 2014 \text { season } \\
(\mathrm{mg})\end{array}$ & \multicolumn{2}{|l|}{ Recovery (mg) } & $\begin{array}{l}\text { Loss } \\
(\mathrm{mg})\end{array}$ \\
\hline \multirow[t]{3}{*}{ Early summer } & APRI10 & 302.3 & $271.5 \pm 6.8 \mathrm{a}$ & $22.0 \pm 1.6 \mathrm{a}$ & 8.7 \\
\hline & CI10 & 267.0 & $242.2 \pm 5.6 b$ & $14.7 \pm 1.9 \mathrm{bcd}$ & 10.2 \\
\hline & APRI50 & 304.0 & $267.5 \pm 9.9 \mathrm{a}$ & $17.3 \pm 0.8 \mathrm{~b}$ & 19.2 \\
\hline & CI10 & 271.4 & $246.2 \pm 8.9 b$ & $13.9 \pm 0.8 \mathrm{~cd}$ & 11.3 \\
\hline & APRI50 & 286.3 & $249.2 \pm 5.8 b$ & $15.3 \pm 1.3 b c$ & 21.8 \\
\hline & CI50 & 251.4 & $204.5 \pm 7.2 c$ & $10.3 \pm 0.9 \mathrm{e}$ & 36.7 \\
\hline
\end{tabular}

${ }^{a}$ Note: APRI10 and APRI50 represent that ${ }^{15} \mathrm{~N}$ was labeled at 10 and $50 \mathrm{~cm}$ soil depths, respectively, under alternate partial root-zone irrigation, and CI10 and CI50 represent that ${ }^{15} \mathrm{~N}$ was labeled at 10 and $50 \mathrm{~cm}$ soil depths, respectively, under conventional irrigation in the $2014 \mathrm{season}$. In the same column, means followed by the same letter (a, b, c, d, or e) do not differ significantly at the $5 \%$ level, according to Duncan's multiple range test. Each value is the mean $\pm \mathrm{SD}$. The amount of ${ }^{15} \mathrm{~N}$ refers to the amount in each soil column. The amount of soil residual ${ }^{15} \mathrm{~N}$ includes that in the $0-100 \mathrm{~cm}$ soil layer.

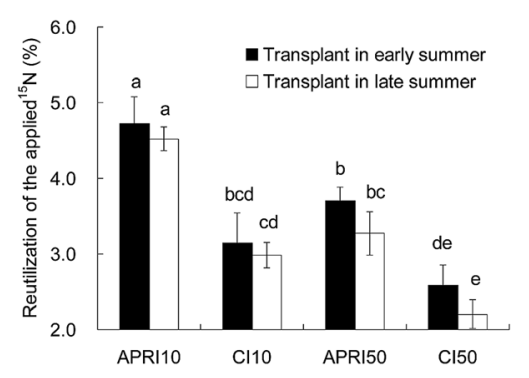

Fig. 5 Reutilization of the applied ${ }^{15} \mathrm{~N}$ by the tomato plants (APRI10 and APRI50 represent that ${ }^{15} \mathrm{~N}$ was labeled at 10 and $50 \mathrm{~cm}$ soil depths, respectively, under alternate partial root-zone irrigation, and $\mathrm{CI} 10$ and $\mathrm{Cl} 50$ represent that ${ }^{15} \mathrm{~N}$ was labeled at 10 and $50 \mathrm{~cm}$ soil depths respectively under conventional irrigation in the 2014 season; means followed by the same letter ( $a, b, c$, d, or e) do not differ significantly at the $5 \%$ level according to Duncan's multiple range test, when the eight means were compared together, and each value is the mean $\pm \mathrm{SD}$ ).

season accounted for $85.4-97.1 \%$ and $2.9-14.6 \%$, respectively, of the total residual ${ }^{15} \mathrm{~N}$ from 2014 . Among the different treatments, APRI10 gave the greatest ${ }^{15} \mathrm{~N}$ recovery and the lowest ${ }^{15} \mathrm{~N}$ loss. With the same irrigation pattern and labeling depth, the ${ }^{15} \mathrm{~N}$ loss was lower when the plants were transplanted in early summer, relative to late summer.

\section{${ }^{15} \mathrm{~N}$ reutilization rate and its influencing factors}

The ${ }^{15}$ NUE ranged from 2.20 to $4.73 \%$ under the different treatments (Fig. 5). The highest ${ }^{15} \mathrm{NUE}$ of $4.73 \%$ was obtained for the tomato plants transplanted in early summer under the APRI10 treatment. Compared to CI, APRI significantly $(p<0.05)$ increased the ${ }^{15} \mathrm{NUE}$ by $43.2-51.7 \%$. However, the transplant time had no significant $(p>0.05)$ effect on ${ }^{15} \mathrm{NUE}$, although a slight decrease in ${ }^{15} \mathrm{NUE}$ was observed for the transplant time of late summer. In addition, it should be noticed that the ${ }^{15} \mathrm{NUE}$ was higher when the ${ }^{15} \mathrm{~N}$ was labeled in a shallower soil layer. Compared to APRI10, a significant $(p<0.05)$ reduction in ${ }^{15} \mathrm{NUE}$ was found for APRI50, for both transplant times. A similar trend was also detected between CI10 and CI50.

The relationship between ${ }^{15} \mathrm{NUE}$ and its influencing factors is shown in Table $5 .{ }^{15}$ NUE had a significant positive relationship with the root dry matter amount $(R=0.74 *)$, root length density $\left(R=0.72^{*}\right)$, total ${ }^{15} \mathrm{~N}\left(R=0.90^{* *}\right)$, mineral ${ }^{15} \mathrm{~N}(R=$ $\left.0.91^{* *}\right)$ and total residual ${ }^{15} \mathrm{~N}$ amount from the 2014 season $(R$ $=0.88^{* *}$ ). This indicated that the ${ }^{15} \mathrm{NUE}$ was closely related to the plant roots, as well as the ${ }^{15} \mathrm{~N}$ amount and its availability.

\section{Discussion}

Much research has been done on the reuse of applied nitrogen by succeeding crops. Liang $^{\mathbf{1}}$ observed a reutilization rate of

Table 5 Factors influencing the reutilization rate of ${ }^{15} \mathrm{~N}$ in the soil-plant system

\begin{tabular}{lllllll}
\hline & ${ }^{15} \mathrm{~N}$ reutilization rate & Root dry matter & Root length density & Total ${ }^{15} \mathrm{~N}$ & Mineral ${ }^{15} \mathrm{~N}$ & ${ }^{15} \mathrm{~N}$ residual by 2014 \\
\hline${ }^{15} \mathrm{~N}$ reutilization rate & 1.00 & $0.74^{b}$ & $0.72^{b}$ & $0.90^{a}$ & $0.91^{a}$ & $0.88^{a}$ \\
Root dry matter & & 1.00 & 0.68 & 0.66 & 0.65 & 0.54 \\
Root length density & & & 1.00 & 0.48 & 0.45 & 0.60 \\
Total ${ }^{15} \mathrm{~N}$ & & & 1.00 & $0.98^{a}$ & $0.81^{b}$ \\
Mineral ${ }^{15} \mathrm{~N}$ & & & & 1.00 & $0.77^{b}$ \\
${ }^{15} \mathrm{~N}$ residual by 2014 & & & & & 1.00
\end{tabular}

${ }^{a}$ Represents significant correlation at the 0.01 level. ${ }^{b}$ Represents significant correlation at the 0.05 level. Total ${ }^{15} \mathrm{~N}$, mineral ${ }^{15} \mathrm{~N}$ and ${ }^{15} \mathrm{~N}$ residual from 2014 are that of the $0-60 \mathrm{~cm}$ soil layer. 
fertilizer nitrogen of $2-9 \%$. Macdonald ${ }^{28}$ reported that approximately $6 \%$ of residual nitrogen was taken up by the succeeding crop. Bhogal ${ }^{29}$ found that equivalent to $8-20 \%$ of the fertilizer nitrogen applied in the previous season was absorbed by the crops in the succeeding season. A four-year case study in eastern China also demonstrated that the total reutilization of fertilizer nitrogen applied in the first season was 11-15\% during the later three seasons, almost reaching half of that in the first season. ${ }^{30}$ Presently, many earlier studies have evaluated the reuse and the redistribution of previous applied nitrogen in the subsequent season. The main difference between our study and those earlier works is that we investigated the fate of previous residual nitrogen under the influence of APRI, a promising irrigation pattern for areas suffering from a water shortage.

We observed a significantly higher ${ }^{15} \mathrm{~N}$ amount in the tomato leaves under APRI when compared to CI; this might be explained as follows: (1) APRI enhanced the availability of soil ${ }^{15} \mathrm{~N},{ }^{31}$ and (2) before this experiment, the soil ${ }^{15} \mathrm{~N}$ amounts in the original soil under different treatments were different, and more ${ }^{15} \mathrm{~N}$ remained in the shallow soil layer under APRI in the previous season (2014). In the previous season, the soil total ${ }^{15} \mathrm{~N}$ amount under APRI treatment was $34.3 \%$ higher compared to that under CI treatment. ${ }^{22}$ The higher ${ }^{15} \mathrm{~N}$ amount in other plant parts, including the stem, roots and fruits, also proved the advantages of APRI in promoting crop nitrogen reuptake. The high plant nitrogen uptake under APRI might also be explained by the higher microbial biomass and nitrogen immobilization in the soil. ${ }^{32}$ An earlier study indicated that the plant nitrogen uptake decreased as the temperature decreased, ${ }^{33}$ possibly due to a reduction in soil mineral nitrogen under lower temperatures. ${ }^{34}$ We found a slight ${ }^{15} \mathrm{~N}$ decrease in the plants transplanted in late summer compared to those transplanted in early summer, though the decrease was not significant $(p>0.05)$.

Besides the ${ }^{15} \mathrm{~N}$ residual effects from the previous season, the redistribution of total ${ }^{15} \mathrm{~N}$ in the $0-100 \mathrm{~cm}$ soil layer may have been affected by the irrigation pattern and ${ }^{15} \mathrm{~N}$ labeling location. Under APRI, the position of the ${ }^{15} \mathrm{~N}$ peak in the soil profile was approximately $10 \mathrm{~cm}$ shallower than that under CI, indicating that nitrogen leaching was weakened by APRI. This confirmed the result of Wang's ${ }^{21}$ study. Besides, Wang also reported that $61.3 \%$ of the ${ }^{15} \mathrm{~N}$ labeled at a $45 \mathrm{~cm}$ depth was moved upwards under APRI. However, in our study, the rate was $26.0-36.8 \%$, possibly due to the fact that we labeled the ${ }^{15} \mathrm{~N}$ in a deeper soil layer, and that our experiment was carried out in the subsequent season when some of the ${ }^{15} \mathrm{~N}$ had been lost in the previous season.

The form of residual nitrogen in the soil greatly affects its bioavailability. ${ }^{35,36}$ Bhogal $^{29}$ pointed out that large amounts of residual fertilizer nitrogen were in the mineral form, while the study by Macdonald ${ }^{37}$ found that major amounts of residual nitrogen were in the organic form, and only small amounts were in the mineral form. These differences primarily related to the amount and type of the applied nitrogen, as well as the soil attributes. ${ }^{38,39}$ After the experiment in the 2015 season, more than $50 \%$ of the residual ${ }^{15} \mathrm{~N}$ in our study was in the mineral form, remaining available in the soil for utilization by the succeeding crop. The higher mineral ${ }^{15} \mathrm{~N}$ under APRI could possibly be explained by the fact that the dry and wet cycles stimulate the mineralization of soil nitrogen. ${ }^{40}$ It was also observed in our study that the mineral ${ }^{15} \mathrm{~N}$ at the transplant time of late summer was lower than that of early summer, which might be attributed to a relatively lower temperature in late summer. Early findings by $\operatorname{Tian}^{\mathbf{4 1}}$ indicated that soil temperature had the greatest contribution to the mineralization of total nitrogen compared to other environmental factors, presenting a positive relationship with the amount of mineral nitrogen.

In our study, APRI significantly $(p<0.05)$ increased ${ }^{15} \mathrm{~N}$ recovery. Namely, APRI contributed to a higher recovery of residual nitrogen, which remained in the soil from the previous season. The reason might be that the relatively lower irrigation amount under APRI limited the amount of ${ }^{15} \mathrm{~N}$ that could leach into the deeper soil layer when compared to $\mathrm{CI}$, thus reducing the risk of ${ }^{15} \mathrm{~N}$ loss. Previous studies by Vázquez ${ }^{42}$ and $\mathrm{Sims}^{43}$ reported that nitrogen losses from the soil occurred primarily when excessive irrigation occurred, leading to variations in the residual nitrogen in different soil layers. Our result was similar to that obtained by Wang; ${ }^{21}$ the main difference was that his experiment was on nitrogen recovery by the in-season crops under APRI.

Nitrogen use efficiency (NUE) is one of the key indicators for evaluating irrigation regimes, together with the water use efficiency, crop yield, quality, etc. ${ }^{\mathbf{4 4 , 4 5}}$ This study observed the nitrogen reuse efficiency as influenced by different irrigation patterns and transplant times, as well as different residual nitrogen amounts. In our study, the transplant time appeared to have little effect on the ${ }^{15}$ NUE; however, the ${ }^{15}$ NUE was significantly $(p<0.05)$ increased by APRI in comparison to CI, for both ${ }^{15} \mathrm{~N}$ labeling depths. It may be that the dry and wet alternate conditions caused by APRI promote pre-stored carbon remobilization, and in most situations, increases in carbon remobilization from vegetative tissues are closely associated with a higher NUE. ${ }^{46,47}$ Except for the mineral ${ }^{15} \mathrm{~N}$ mentioned earlier, it was found that ${ }^{15} \mathrm{NUE}$ correlated significantly with the root dry matter $\left(R=0.74^{*}\right)$, as well as the root length density ( $R$ $=0.72 *$ ). The higher ${ }^{15}$ NUE under APRI might also be explained by the fact that APRI could cause alternate water stress in the root-zone and promote compensatory root growth, thereby regulating the functioning of the crop root system. ${ }^{15}$ Significantly higher root dry weights under APRI or dry-wet cycling have been reported by many previous studies. ${ }^{45,48,49}$ It cannot be ignored that the ${ }^{15} \mathrm{NUE}$ was also closely related to the total ${ }^{15} \mathrm{~N}$ residual amount from the previous season $\left(R=0.88^{* *}\right)$, which is in line with the findings in tobacco. ${ }^{30}$

Our study revealed the impact of APRI on the fate of ${ }^{15} \mathrm{~N}$ in the subsequent growing season. However, caution should be taken as this experiment was conducted under greenhouse conditions, and the environments might be different under field conditions; thus more research under various growth conditions needs to be carried out in the future.

\section{Conclusion}

After the experiment in the 2015 season, it was found that 81.3$90.7 \%$ of the residual ${ }^{15} \mathrm{~N}$ from the 2014 season remained in the 
0-100 cm soil layer, 4.1-7.3\% was absorbed by the 2015-season tomato plants, and $2.9-14.6 \%$ was lost. The ${ }^{15} \mathrm{~N}$ reutilization rates (defined as the ratio of plant ${ }^{15} \mathrm{~N}$ uptake to total ${ }^{15} \mathrm{~N}$ applied in 2014) were $2.20-4.73 \%$ under the different treatments. Compared to CI, APRI significantly $(p<0.05)$ increased the accumulation amount of ${ }^{15} \mathrm{~N}$ in the $0-100 \mathrm{~cm}$ soil layer, as well as the plant ${ }^{15} \mathrm{~N}$ uptake and reutilization rate, and APRI also contributed to a greater ${ }^{15} \mathrm{~N}$ distribution in the shallower soil layers. Overall, the tomato ${ }^{15} \mathrm{~N}$ reutilization rate was found to be significantly $(p<0.05)$ higher with ${ }^{15} \mathrm{~N}$ labeled in the $0-20 \mathrm{~cm}$ soil layer in comparison to the $40-60 \mathrm{~cm}$ layer, and insignificantly higher when transplanting in early summer compared to late summer. Furthermore, the ${ }^{15} \mathrm{~N}$ reutilization rate had a significant positive relationship with the root dry matter $(R=$ $\left.0.74^{*}\right)$, root length density $\left(R=0.72^{*}\right)$, mineral ${ }^{15} \mathrm{~N}\left(R=0.91^{* *}\right)$ and total residual ${ }^{15} \mathrm{~N}$ from $2014\left(R=0.88^{* *}\right)$. It was concluded from our study that an enlarged root system and a high nitrogen availability under APRI might have contributed to the higher ${ }^{15} \mathrm{~N}$ reutilization rate.

\section{Acknowledgements}

The work was financed by Natural Science Foundation of Fujian Province (2016J05069), Young Talent Foundation of Horticultural College of Fujian Agriculture and Forest University (61201400705), Postdoctoral Funds of Fujian A\&F University (132300198), Key Project on Poor Supporting of Fujian Province (K1516035A), as well as New Technology Project on Irrigation and Drainage of Tiaozini (SF-201724).

\section{References}

1 B. Liang, W. Zhao, X. Yang and J. Zhou, Field Crops Res., 2013, 144, 126-134.

2 S. Zhang, P. Gao, Y. Tong, D. Norse, Y. Lu and D. Powlson, Agric., Ecosyst. Environ., 2015, 209, 89-99.

3 T. Darwish, T. Atallah, M. El Moujabber and N. Khatib, Agric Water Manag., 2005, 78, 152-164.

4 J. Zhang, X. H. Shao and T. T. Chang, J. Food, Agric. Environ., 2012, 10, 1409-1412.

5 A. Cockburn, C. W. Heppner and J. L. C. M. Dorne, in Encyclopedia of Food Safety, Academic Press, Waltham, 2014, pp. 332-336.

6 M. J. Wright and K. L. Davison, in Advances in Agronomy, ed. A. G. Norman, Academic Press, 1964, vol. 16, pp. 197-247.

7 J. Y. Yang, C. F. Drury, R. De Jong, E. C. Huffman, X. M. Yang and K. Reid, Ecol. Modell., 2013, 267, 26-38.

8 A. M. Davis, M. Tink, K. Rohde and J. E. Brodie, Agric., Ecosyst. Environ., 2016, 223, 190-196.

9 K. Granlund, K. Rankinen, R. Etheridge, P. Seuri and J. Lehtoranta, Agric. Sys., 2015, 133, 167-176.

10 H. Du, Doctor, Chinese Academy of Sciences, 2007.

11 M. Hou, X. Shao, Q. Jin and X. Gao, Arch. Agron. Soil Sci., 2016, 1-10.

12 G. Ojeda, D. Tarrasón, O. Ortiz and J. M. Alcañiz, Agric., Ecosyst. Environ., 2006, 117, 49-56.
13 D. Stefanelli, I. Goodwin and R. Jones, Food Res. Int., 2010, 43, 1833-1843.

14 P. Wu, C. Xia, F. Liu, Y. Wu and Y. He, Appl. Math. Model., 2016, 40, 8108-8124.

15 Q. Zhang, S. Wu, C. Chen, L.-Z. Shu, X.-J. Zhou and S.-N. Zhu, Agric Water Manag., 2014, 142, 56-65.

16 L. I. N. Yechun, Z. Zhaohai, R. E. N. Changzhong and H. U. Yuegao, Procedia Eng., 2012, 28, 33-42.

17 Y. Wu, S. Zhou, Z. Wang and X. Zhang, Acta Ecol. Sin., 2005, 25, 1869-1873.

18 S. Z. Kang and J. H. Zhang, J. Exp. Bot., 2004, 55, 2437-2446.

19 S. Du, S. Kang, F. Li and T. Du, Agric Water Manag., 2017, 179, 178-182.

20 Z. Wei, T. Du, J. Zhang, S. Xu, P. J. Cambre and W. J. Davies, Agric Water Manag., 2016, 165, 33-43.

21 C. Wang, P. Zhu, L. Shu, J. Zhu, H. Yu, Y. Zhan and M. Yuan, Nongye Gongcheng Xuebao, 2014, 30, 92-101.

22 M. Hou, Q. Jin, X. Lu, J. Li, H. Zhong and Y. Gao, Front. Plant Sci., 2017, 8, 00666.

23 J. Lv, J. Gansu Agric. Univ., 2013, 2, 37-41.

24 T. S. Du, S. Z. Kang, J. H. Zhang, F. S. Li and X. T. Hu, Agric Water Manag., 2006, 84, 41-52.

25 X.-E. Liu, X. G. Li, R.-Y. Guo, Y. Kuzyakov and F.-M. Li, Eur. J. Agron., 2015, 70, 71-77.

26 C. Carranca, A. de Varennes and D. E. Rolston, Eur. J. Agron., 1999, 11, 145-155.

27 M. Hou and X. Shao, Zemdirbyste-Agriculture, 2016, 103, 221228.

28 A. J. Macdonald, P. R. Poulton, E. A. Stockdale, D. S. Powlson and D. S. Jenkinson, Plant Soil, 2002, 246, 123-137.

29 A. Bhogal, A. D. Rochford and R. Sylvester-Bradley, J. Agric. Sci., 2000, 135, 139-149.

30 M. Hou, X. Shao, Y. Zhai, Y. Yuan and F. Ding, Nongye Gongcheng Xuebao, 2016, 32, 118-123.

31 Z. Wang, F. Liu, S. Kang and C. R. Jensen, Environ. Exp. Bot., 2012, 75, 36-40.

32 C. Liu, G. H. Rubæk, F. Liu and M. N. Andersen, Agric Water Manag., 2015, 159, 66-76.

33 C. E. Demurtas, G. Seddaiu, L. Ledda, C. Cappai, L. Doro, A. Carletti and P. P. Roggero, Agric., Ecosyst. Environ., 2016, 219, 83-92.

34 L. Ma, Acta Pedol. Sin., 2010, 47, 286-294.

35 G. Agegnehu, P. N. Nelson and M. I. Bird, Soil Tillage Res., 2016, 160, 1-13.

36 R. H. Masunga, V. N. Uzokwe, P. D. Mlay, I. Odeh, A. Singh, D. Buchan and S. De Neve, Appl. Soil Ecol., 2016, 101, 185193.

37 A. J. Macdonald, P. R. Poulton, D. S. Powlson and D. S. Jenkinson, J. Agric. Sci., 1997, 129, 125-154.

38 X. H. He, M. G. Xu, G. Y. Qiu and J. B. Zhou, J. Plant Ecol., 2009, 2, 107-118.

39 B. Liang, X. Y. Yang, X. H. He and J. B. Zhou, Biol. Fertil. Soils, 2011, 47, 121-128.

40 Y. Sun, F. Yan and F. Liu, Agric Water Manag., 2013, 128, 8591.

41 M. Tian, Nat. Sci., 2004, 25, 299-303. 
42 N. Vázquez, A. Pardo, M. L. Suso and M. Quemada, Agric., Ecosyst. Environ., 2006, 112, 313-323.

43 J. T. Sims, R. R. Simard and B. C. Joern, J. Environ. Qual., 1998, 27, 277-293.

44 M. H. Shahrokhnia and A. R. Sepaskhah, Agric Water Manag., 2016, 172, 18-30.

45 Z. Wang, W. Zhang, S. S. Beebout, H. Zhang, L. Liu, J. Yang and J. Zhang, Field Crops Res., 2016, 193, 54-69.
46 J. C. Yang and J. H. Zhang, New Phytol., 2006, 169, 223-236. 47 B. Ehdaie, Crop Sci., 1995, 35, 1617-1626.

48 G. Chu, Z. Wang, H. Zhang, L. Liu, J. Yang and J. Zhang, Food Energy Secur., 2015, 4, 238-254.

49 H. Zhang, Y. G. Xue, Z. Q. Wang, J. C. Yang and J. H. Zhang, Crop Sci., 2009, 49, 2246-2260. 